\title{
BMJ Global Health Words matter: political and gender analysis of speeches made by heads of government during the COVID-19 pandemic
}

\author{
Sara Dada (1) , ${ }^{1,2,3}$ Henry Charles Ashworth (D) , ${ }^{1,3,4}$ Marlene Joannie Bewa (D) ,3,5 \\ Roopa Dhatt (i) $3,6,7$
}

To cite: Dada S, Ashworth HC, Bewa MJ, et al. Words matter: political and gender analysis of speeches made by heads of government during the COVID-19 pandemic. BMJ Global Health 2021;6:e003910. doi:10.1136/ bmjgh-2020-003910

Handling editor Seye Abimbola

- Additional material is published online only. To view, please visit the journal online (http://dx.doi.org/10.1136/ bmjgh-2020-003910).

Received 8 September 2020 Revised 26 November 2020 Accepted 3 December 2020

Check for updates

(c) Author(s) (or their employer(s)) 2021. Re-use permitted under CC BY. Published by BMJ.

For numbered affiliations see end of article.

Correspondence to

Sara Dada;

sara.dada@ucdconnect.ie

\section{ABSTRACT}

Background The COVID-19 pandemic has put a spotlight on political leadership around the world. Differences in how leaders address the pandemic through public messages have practical implications for building trust and an effective response within a country.

Methods We analysed the speeches made by 20 heads of government around the world (Bangladesh, Belgium, Bolivia, Brazil, Dominican Republic, Finland, France, Germany, India, Indonesia, New Zealand, Niger, Norway, Russia, South Africa, Scotland, Sint Maarten, United Kingdom, United States and Taiwan) to highlight the differences between men and women leaders in discussing COVID-19. We used an inductive analytical approach, coding speeches for specific themes based on language and content.

Findings Five primary themes emerged across a total of 122 speeches on COVID-19, made by heads of government: economics and financial relief, social welfare and vulnerable populations, nationalism, responsibility and paternalism, and emotional appeals. While all leaders described the economic impact of the pandemic, women spoke more frequently about the impact on the individual scale. Women leaders were also more often found describing a wider range of social welfare services, including: mental health, substance abuse and domestic violence. Both men and women from lowerresource settings described detailed financial relief and social welfare support that would impact the majority of their populations. While 17 of the 20 leaders used war metaphors to describe COVID-19 and the response, men largely used these with greater volume and frequency. Conclusion While this analysis does not attempt to answer whether men or women are more effective leaders in responding to the COVID-19 pandemic, it does provide insight into the rhetorical tools and types of language used by different leaders during a national and international crisis. This analysis provides additional evidence on the differences in political leaders' messages and priorities to inspire citizens' adhesion to the social contract in the adoption of response and recovery measures. However, it does not consider the influence of contexts, such as the public audience, on leaders' strategic communication approaches.

\section{Key questions}

What is already known?

- It has been established from both previous disease outbreaks and vaccination campaigns that the way health messages are framed and communicated has a profound impact on public trust and compliance with public health measures.

- A pandemic or infectious disease outbreak generally requires action by all citizens to adhere to public health measures that will limit transmission, and therefore, ill health and death.

- From the beginning of the COVID-19 pandemic, different political leaders have employed unique approaches to communicating about the pandemic and highlighting their own national priorities.

What are the new findings?

- These findings provide an in-depth analysis of the major themes discussed across public addresses made by heads of government and the rhetoric used distinctly by men and women leaders: economics and financial relief, social welfare and vulnerable populations, nationalism, responsibility and paternalism, and emotional appeals.

- While both men and women recognise the economic implications of the pandemic, women leaders spoke more frequently than men about the impact on the local level or on individuals and a wider variety of social welfare services to cushion financial shocks.

- All leaders employed various types of emotional appeals to mobilise the public, but men used war metaphors and aggressive language with greater frequency than women.

\section{BACKGROUND}

The novel COVID-19 pandemic has shone a spotlight on political leadership and decision making around the world. These decisions made by political leaders have critical implications for scientific research, vaccine development, healthcare delivery and systems, social and economic policy measures to contain the 


\section{Key questions}

What do the new findings imply?

- While this study does not assert that one gender of leader, men or women, is more effective in responding to the pandemic than another, it does outline the varied approaches that generally correlate with gender and provide some context for how this language may influence response.

- The differences in leaders' messaging and language style is influenced by a range of factors including social, political, historical, economic and geographical contexts. Societal norms and expectations from the public audience may also influence how a leader chooses to address their citizens, which must be considered in assessing the efficacy of their communication.

- Most importantly, these findings call for further analysis on how discourse impacts not only current COVID-19 response but future plans for vaccine deployment and economic and social recovery.

pandemic and ultimately for the health, well-being and life of citizens. In the current chaotic context, leadership and language matter; the ability of heads of governments and global health authority figures to communicate publicly on the impact of COVID-19 and the measures taken to mitigate risks are critical and closely scrutinised. Citizens' perceptions, behaviours and attitudes are significantly influenced by the type and quality of information or public services announcements to which they are exposed. ${ }^{1}$

Responses to the pandemic have varied significantly across countries and continents and are influenced not only by the magnitude of the pandemic, but also by preexisting preparedness mechanisms and national leadership. For example, politicians' statements are likely to have a powerful impact on citizen's adherence to social distancing measures or mask-wearing. A recent study analysing the context and chronology of presidential speeches in Brazil revealed the relationship between statements made by President Bolsonaro on COVID-19 prevention measures and adherence to social distancing policies. ${ }^{2}$ Additional research has noted that, while the difference is not statistically significant, countries led by women have seen better public health metrics in terms of COVID-19 response compared with countries led by men ${ }^{3}$ and are correlated with more proactive policy response such as implementing lockdown measures. ${ }^{4}$ While risk perception and health behaviours may be non-partisan in theory, citizens' behaviours are likely influenced by political leaders' messages and calls to action or inaction. ${ }^{2}$

At the time of writing, COVID-19 has not yet been eliminated in any but the smallest island states; some countries that had low early mortality rates are experiencing a resurgence and a second wave of infections is predicted before a vaccine is in widespread use. It would, therefore, be premature to conclude that some countries have done better in pandemic response than others since the picture may yet change. It is clear, however, that political leaders take different approaches and that further work is needed to analyse how these influence public health messaging and public trust. In particular, it is worthwhile to consider if and how these differences are influenced by gender. This study analyses the public speeches and statements made by heads of government in 20 countries around the world. The purpose is to understand the different language, rhetoric and priorities expressed by men and women leaders in responding to the COVID-19 pandemic.

\section{METHODS \\ Setting}

We set out to analyse official statements made by heads of government of the United Nations Security Council 2020 members (Belgium, China, Dominican Republic, Estonia, France, Germany, Indonesia, Niger, Russian Federation, Saint Vincent and the Grenadines, South Africa, Tunisia, the UK, the USA, Vietnam), Brazil, Russia, India, China, South Africa, and nation-states with women heads of government (Bangladesh, Barbados, Bolivia, Belgium, Denmark, Finland, Germany, Iceland, Namibia, New Zealand, Norway, Scotland, Serbia, Sint Maarten, Taiwan). We restricted the timeframe to 26 February through 6 April 2020 in order to capture the month of March, the beginning of when COVID-19 was spreading rapidly around the world and when international leaders began to respond actively. We recognise that gender is not binary, but for the purposes of this study have categorised political leaders as 'man' or 'woman' according to their assumed public gender identity, in the absence of other information on gender identity.

\section{Data collection}

We searched for national addresses, statements or speeches made to the public by all 29 countries' heads of government (online supplemental appendix 1). Where fewer than two formal speeches were available, we also searched for press briefings (including only the introductory statements made by the head of government, before entertaining questions from the press), statements made to governing bodies (speeches to parliament), and other statements aimed towards the general public (podcasts, video announcements) and included these where available.

Written speeches were found on the public domain and via government websites. Where only a video was available, the speech was transcribed and cross-checked by a native speaker. All non-English speeches were translated into English using Google Translate and cross-checked by speakers fluent in the original language. In order to have a comparable final dataset, we aimed to include a range of geographic and political contexts that could be matched across the groups of men and women heads of government. We also aimed for gender parity and included the countries with the most available data in order to have a balanced pool. Table 1 exhibits the final list of included countries and the number of statements made during the study period. Countries were most commonly excluded 
Table 1 Included countries and number of speeches available

\begin{tabular}{|c|c|c|c|c|c|}
\hline Country & Leader & Man/woman & Region & $\begin{array}{l}\text { Rationale for } \\
\text { inclusion }\end{array}$ & $\begin{array}{l}\text { No of } \\
\text { speeches }\end{array}$ \\
\hline Bangladesh & Hasina & Woman & Asia & Woman & 1 \\
\hline Belgium & Wilmès & Woman & Europe & UNSC, woman & 3 \\
\hline Bolivia & Áñez & Woman & South America & Woman & 7 \\
\hline Brazil & Bolsonaro & Man & South America & BRICS & 4 \\
\hline Dominican Republic & Medina & Man & Caribbean & UNSC & 2 \\
\hline Finland & Marin & Woman & Europe & Woman & 3 \\
\hline France & Macron & Man & Europe & UNSC & 2 \\
\hline Germany & Merkel & Woman & Europe & UNSC, Woman & 4 \\
\hline India & Modi & Man & Asia & BRICS & 4 \\
\hline Indonesia & Widodo & Man & Asia & UNSC & 5 \\
\hline New Zealand & Ardern & Woman & Oceania & Woman & 3 \\
\hline Niger & Issoufou & Man & Africa & UNSC & 2 \\
\hline Norway & Solberg & Woman & Europe & Woman & 12 \\
\hline Russia & Putin & Man & Europe/Asia & BRICS, UNSC & 2 \\
\hline Scotland & Sturgeon & Woman & Europe & Woman & 14 \\
\hline South Africa & Ramaphosa & Man & Africa & BRICS, UNSC & 3 \\
\hline Sint Maarten & Jacobs & Woman & Caribbean & Woman & 12 \\
\hline Taiwan & Ing-wen & Woman & Asia & Woman & 2 \\
\hline UK & Johnson & Man & Europe & UNSC & 12 \\
\hline USA & Trump & Man & North America & UNSC & 25 \\
\hline
\end{tabular}

BRICS, Brazil, Russia, India, China, South Africa; UNSC, United Nations Security Council.

because there were no public statements or not enough statements available (online supplemental appendix 1).

\section{Analysis}

Speech transcripts were uploaded and analysed into NVivo. Two independent authors (SD and HCA) used a grounded theory approach to analyse the speeches and coded themes that emerged in the data. A sample of six transcripts from different countries was used to develop the codebook applied to the rest of the dataset and was checked for data saturation.

\section{Patient and public involvement}

This research did not involve patients or the public in the design, conduct, reporting, or dissemination plans.

\section{RESULTS}

A total of 20 countries across six continents were included in this analysis, with 122 speeches analysed (online supplemental appendix 2 provides speech sources). This set of countries included 10 men and 10 women who served as heads of government. Both groups of countries ranged in geographical location, political system, and economic productivity. In the dataset of 122 speeches, 61 were delivered by women and 61 by men. Table 2 provides some contextual information on the included countries, such as democracy index and gender development index scores and ranked by COVID-19 case count as of 30 June 2020.

Five major themes emerged across speeches: the economy and financial relief, social welfare and vulnerable populations, nationalism, responsibility and paternalism, and emotional appeals. While speeches and statements covered a wide range of content, these themes were where differences in priorities and language across countries and across leaders were most distinct. Our final interrater reliability, Kappa score, was 0.81, suggesting moderate to strong agreement among coders. ${ }^{5}$

\section{The economy and financial relief}

The economy was a central theme across leaders regardless of geography, level of gross domestic product or gender. Eighteen of the 20 leaders, excluding India's Modi and Bangladesh's Hasina, specifically detailed the programmes that would provide financial relief. Seven leaders (three women-Bolivia, Germany, Norway; four men-France, Indonesia, Russia, USA) focused on small businesses across 20 speeches, while six leaders (three women-Germany, Norway, Scotland; three menDominican Republic, South Africa, USA) discussed large businesses across 21 speeches. Informal economies were discussed by three leaders (one woman-Norway; two men-Dominican Republic, South Africa) in five speeches. 
Table 2 Included countries ranked by COVID-19 case rate, including Gross Domestic Product (GDP) per capita, democracy index and gender development index scores

\begin{tabular}{|c|c|c|c|c|c|c|c|}
\hline Country & M/W & $\begin{array}{l}\text { Cases per capita } \\
\text { as of } 30 \mathrm{June}^{31}\end{array}$ & $\begin{array}{l}\text { GDP per capita } \\
2019{\text { (US } \$)^{32}}^{2}\end{array}$ & $\begin{array}{l}\text { Democracy } \\
\text { Index } 2019^{33}\end{array}$ & $\begin{array}{l}\text { Democracy } \\
\text { Index }\end{array}$ & $\begin{array}{l}\text { Gender } \\
\text { Development } \\
\text { Index } 2018^{34}\end{array}$ & $\begin{array}{l}\text { Gender } \\
\text { Development } \\
\text { Index Group }\end{array}$ \\
\hline USA & M & $0.7667 \%$ & 65118.40 & 7.96 & Flawed & 0.991 & 1 \\
\hline Brazil & $\mathrm{M}$ & $0.6324 \%$ & 8717.20 & 6.86 & Flawed & 0.995 & 1 \\
\hline Belgium & W & $0.5300 \%$ & 46116.70 & 7.64 & Flawed & 0.972 & 2 \\
\hline UK & M & $0.4595 \%$ & 42300.30 & 8.52 & Full & 0.967 & 2 \\
\hline Russia & M & $0.4439 \%$ & 11585.00 & 3.11 & Authoritarian & 1.015 & 1 \\
\hline Scotland & W & $0.3473 \%$ & $37,400.21^{35}$ & $\mathrm{~N} / \mathrm{A}$ & $\mathrm{N} / \mathrm{A}$ & N/A & N/A \\
\hline $\begin{array}{l}\text { Dominican } \\
\text { Republic }\end{array}$ & M & $0.2933 \%$ & 8282.10 & 6.54 & Flawed & 1.003 & 1 \\
\hline Bolivia & W & $0.2701 \%$ & 3552.10 & 4.84 & Hybrid & 0.936 & 3 \\
\hline South Africa & M & $0.2432 \%$ & 6001.40 & 7.24 & Flawed & 0.984 & 1 \\
\hline France & M & $0.2404 \%$ & 40493.90 & 8.12 & Full & 0.984 & 1 \\
\hline Germany & W & $0.2319 \%$ & 46258.90 & 8.68 & Full & 0.968 & 2 \\
\hline Sint Maarten & W & $0.1796 \%$ & $23367(2018)^{36}$ & $\mathrm{~N} / \mathrm{A}$ & $\mathrm{N} / \mathrm{A}$ & N/A & N/A \\
\hline Norway & W & $0.1633 \%$ & 75419.60 & 9.87 & Full & 0.990 & 1 \\
\hline Finland & W & $0.1301 \%$ & 48685.90 & 9.25 & Full & 0.990 & 1 \\
\hline Bangladesh & W & $0.0861 \%$ & 1855.70 & 5.88 & Hybrid & 0.893 & 5 \\
\hline India & M & $0.0411 \%$ & 2104.10 & 6.90 & Flawed & 0.829 & 5 \\
\hline New Zealand & W & $0.0244 \%$ & 42084.4 & 9.26 & Full & 0.963 & 2 \\
\hline Indonesia & M & $0.0201 \%$ & 4135.60 & 6.48 & Flawed & 0.937 & 3 \\
\hline Niger & M & $0.0044 \%$ & 554.60 & 3.29 & Authoritarian & 0.298 & 5 \\
\hline Taiwan & W & $0.0019 \%$ & $24827.89^{37}$ & 7.73 & Flawed & $\mathrm{N} / \mathrm{A}$ & N/A \\
\hline
\end{tabular}

N/A, not applicable.

While each country's economic context and priorities differ and likely influences the heads of government, all leaders highlighted the devastating economic impacts of COVID-19. Almost all leaders made reference to financial support for families, small businesses and larger corporations. However, there was a difference in how men and women addressed this economic impact. Despite the near equal number of speeches with economic references made across genders, this analysis demonstrates that women leaders tended to prioritise discussing the economy at the level of individuals and small businesses, while their men counterparts more often focused on larger businesses and corporations (table 3). Besides emphasising economic support for individuals and

Table 3 Leaders' references to small versus big businesses

\begin{tabular}{|c|c|c|c|c|c|c|}
\hline Country & $\begin{array}{l}\text { No of references } \\
\text { to small } \\
\text { businesses }\end{array}$ & $\begin{array}{l}\text { No of speeches } \\
\text { (of total } \\
\text { speeches) }\end{array}$ & $\begin{array}{l}\text { Average reference } \\
\text { coverage per } \\
\text { speech, \% }\end{array}$ & $\begin{array}{l}\text { No of references } \\
\text { to big } \\
\text { businesses }\end{array}$ & $\begin{array}{l}\text { No of speeches } \\
\text { (of total } \\
\text { speeches) }\end{array}$ & $\begin{array}{l}\text { Average reference } \\
\text { coverage per } \\
\text { speech, } \%\end{array}$ \\
\hline Bolivia* & 5 & 3 (of 3) & 5.30 & -- & -- & -- \\
\hline Dominican Republic & -- & -- & -- & 2 & 1 (of 2) & 1.77 \\
\hline France & 1 & 1 (of 2) & 0.27 & -- & -- & -- \\
\hline Germany* & 1 & 1 (of 4 ) & 10.39 & 2 & 1 (of 4) & 5.28 \\
\hline Indonesia & 1 & 1 (of 4$)$ & 3.03 & -- & -- & -- \\
\hline Norway* & 4 & 2 (of 12) & 4.05 & 8 & 3 (of 12) & 5.03 \\
\hline Russia & 2 & 1 (of 2) & 2.32 & -- & -- & -- \\
\hline Scotland* & -- & -- & -- & 3 & 2 (of 14) & 3.34 \\
\hline South Africa & -- & -- & -- & 2 & 1 (of 3) & 1.13 \\
\hline USA & 28 & 14 (of 25) & 2.69 & 55 & 12 (of 25) & 8.05 \\
\hline
\end{tabular}

${ }^{*}$ countries with women heads of government. 
employees, a woman (Scotland's Sturgeon) was the only leader to discuss labour unions. This connects to a larger theme across categories that women demonstrated a more people-centred approach compared with the men.

Of the men who discussed economic support to smaller businesses, American President Donald Trump and French President Emmanuel Macron stood out. Macron specifically focused on providing unconditional support to business owners. On 12 March he stated:

We will not add the fear of bankruptcy for entrepreneurs, concerns about unemployment and the challenge of making ends meet at the end of the month to health worries. Every effort will therefore be made to protect our employees and to protect our companies, regardless of the cost.

Trump frequently discussed supporting small businesses, and referenced them in 14 of his 25 speeches. However, these references were few compared with the emphasis he put on addressing large corporations and chief executive officers (CEOs). The first topic Trump discussed in half of his first ten speeches was the economic aspects of COVID-19, rather than the medical or health repercussions for society. Men leaders tended to focus more on supporting large business and emphasising overall national economic recovery over individual support. This either came in subtle forms like Brazilian President Jair Bolsonaro stating on 3 March, 'We have a mission: to save lives, without leaving jobs behind' or in more overt forms such as Trump directly naming and thanking companies and inviting their CEOs to speak at formal press briefings, particularly on 13,15 and 30 March.

Women leaders who discussed supporting small businesses highlighted the importance of protecting workers as well as individuals and families. Bolivia's interim President Jeanine Áñez, described on 15 March how programmes for "small and medium-sized entrepreneurs who are suffering and who will suffer due to this health crisis' would also 'help Bolivian families who will suffer an economic impact from the coronavirus.' In Scotland, First Minister Nicola Sturgeon stated in an address on 22 March, 'To the vast majority of employers I say thisthe solution to the challenges that I know you are facing now is not key worker status. It is new shift patterns, it is working from home, it is dropping non-essential tasks. And that is what you can do to help all of us save lives.' Women leaders were also specific about their economic support for small businesses. Finland's Prime Minister Sanna Marin and Germany's Chancellor Angela Merkel both detailed financial programmes and stimulus funds for small businesses.

\section{Vulnerable populations and social welfare}

German Chancellor Merkel described the relationship between the economic and social impacts of the pandemic best in a speech on 23 March with the statement, "many are experiencing a social emergency due to the economic impact.' The COVID-19 pandemic has catalysed new social emergencies and deepened chronic challenges including social inequities. While the two are intertwined, distinct vulnerable populations may require distinct forms of social welfare. Just as the response to economic concerns varied across leaders, so did their response to supporting new and longstanding vulnerable populations through different forms of social welfare in their speeches.

With regard to specific vulnerable populations, only women heads of government noted the vulnerability of migrants and refugees, individuals with mental health and substance use issues, and victims of domestic violence. When women leaders spoke about and to these populations, they did so with strong, empathetic and persuasive language. For example, Bolivia's Áñez specifically called out and condemned all acts of violence perpetrated against women:

We have received many complaints about sexist violence and domestic violence during these days of quarantine. I want to be very clear at this point. We are going to fall with the full weight of the law before those who commit violence against women and against families. And they already know me. I am going to be firm, I am going to be firm in the defense of Bolivian women and families.

Immigrants, asylum seekers, and refugees have heightened vulnerability in this pandemic. The only leaders to mention these populations, and describe support for them were Belgium's Prime Minister Sophie Wilmès and New Zealand's Prime Minister Jacinda Ardern. For example on 5 April, Wilmès stated, "many decisions have also been taken in the field of mobility, asylum and support for the most vulnerable people. These decisions were taken by the federal government as a team, in collaboration with parliaments and the social partners.'

Men and women both mentioned other vulnerable populations including children, the sick or immunocompromised, and the elderly consistently across regions. These references were both in relation to how collectively each country needed to take care of these populations, and also the specific actions each government was taking. Typical comments include ones from Johnson on 12 March, 'The most important task will be to protect our elderly and most vulnerable people during the peak weeks when there is the maximum risk of exposure to the disease and when the National Health Service (NHS) will be under the most pressure' and Sturgeon on 17 March, 'First, people who are over 70, second people with underlying health conditions for which they get the influenza vaccine, and third women who are pregnant. We are strongly advising them to stay at home as much as possible, and to significantly reduce unnecessary social contact.' Some leaders particularly stood out including Norwegian Prime Minister Erna Solberg's focus on children, which included a press briefing specifically for children.

In terms of social welfare, all men and women leaders mentioned unemployment, healthcare costs and access, 
food and housing. Leaders of low and middle-income countries stressed access to food. Examples include Bangladeshi Prime Minister Sheikh Hasina on 25 March, 'Assistance will be provided to low-income people in their respective villages under the "Homecoming" program. Free house, 6 months food and cash will be provided to the homeless and landless' and South African President Cyril Ramaphosa on 30 March, 'The elderly and the frail need people to care for them. Some of those who live on the streets are without shelter or food.'

Women leaders dove to a deeper depth on social welfare particularly related to the vulnerable and need for social support. This was seen in how their mentioning less traditional, yet equally necessary forms of social welfare including day care, mental health and support for victims of domestic violence and sexual assault. Only Áñez and Sturgeon directly addressed domestic violence and measures to combat the reports of increased incidence during the pandemic. Another example is Sturgeon's comprehensive plan to provide equitable support for mental health described on 27 March:

We are putting an additional $£ 3.8$ million immediately into the NHS's mental health support services. $£ 0.5$ million of that will support for the Breathing Space phone line and web service, and £2.1 million will be for the NHS’s Mental Health Hub ... The mental health hub will expand its staffing in the coming weeks, so that it can become available to the public 24 hours a day, 7 days a week.

This focus was consistent across most women leaders and can be seen in how Sint Maarten's Prime Minister Silveria Jacobs mentioned it in over half of her speeches, often with specific actions such as on 20 March, 'designate the first hour of business to senior citizens, as well as vulnerable persons such as pregnant women and persons with children. This is in order to minimise contact.'

\section{Nationalism}

Reacting to a pandemic in a globalised society brings up an interesting dichotomy of national versus international interests. In our analysis, the theme of nationalism appeared in a number of ways in leaders' responses. These include actions such as enforcing border control and rhetoric such as blame, advocacy for global cooperation and urging a sense of patriotic duty and sacrifice.

While only three leaders incorporated a tactic of blame in their speeches (Áñez, Bolsonaro and Trump), each did so to a different extent. Trump blamed a third party in 14 of his 25 speeches. However, in only one speech on 15 March, Áñez said 'we receive a very neglected and flawed health system. So now our effort must be double'. This reflects a similar theme in Trump's speeches, such as on 5 April when he stated: 'And you remember, we inherited a broken system.' However, the biggest target of Trump's blame remains China. He is the only leader to consistently refer to COVID-19 as 'the Chinese virus,' rather than using its official or scientific name. On 14 March, he stated: 'It's something that nobody expected. It came out of China, and it's one of those things that happened.'
Beyond this, Trump and Bolsonaro both blame China and the media for their roles in the pandemic. On 24 March, Bolsonaro accused the media of stirring up panic in the country: 'Considerable part of the media went against the grain. They spread exactly the feeling of fear, with the announcement of the large number of victims in Italy as their flagship.'

While leaders of 13 countries (8 women-Bangladesh, Bolivia, Finland, Germany, New Zealand, Norway, Sint Maarten, Taiwan; 5 men-Dominican Republic, France, Niger, South Africa, USA) discussed limited international borders or suspending flights to or from specific regions, Trump stressed travel restrictions taking an isolationist approach. On 24 March, he emphasised the need for self-reliance:

We should never be reliant on a foreign country for the means of our own survival. I think we've learned a lot. We've learned a lot. This crisis has underscored just how critical it is to have strong borders and a robust manufacturing sector... America will never be a supplicant nation. We will be a proud, prosperous, independent, and selfreliant nation. We will embrace commerce with all, but we will be dependent on none.

This mentality contrasted the emphasis several other leaders placed on global cooperation. Four nations led by men discussed the value and importance of global cooperation (France, Niger, UK, USA), while seven women-led nations did the same (Bangladesh, Bolivia, Finland, Germany, Norway, Sint Maarten, Taiwan). Even among the men who did discuss global cooperation, they discussed it far less, with just one mention each, except for Trump who on three occasions described working with other nations referring to how America was 'helping other nations-many other nations; we're helping them a lot.' On 12 March, Macron stressed 'This virus doesn't have a passport. We need to join forces, coordinate our responses and cooperate' and on the 17th, Johnson simply said 'while we need national unity, we also need international cooperation.' On 27 March, Niger's President Mahamadou Issoufou highlighted the role of globalisation:

I appeal to international solidarity to support the implementation of this plan. This solidarity is more than ever justified because the increase in the speed of means of transport has canceled the distances between regions of the world and between countries... More solidarity and more equality, this must be the rallying cry, this must be the new creed. We must share both the risks and the benefits of globalization.

When considering the women, Marin, Merkel and Solberg stressed collaboration across the European region and Áñez emphasised cooperation with the WHO. Sint Maarten, as an overseas territory of the Netherlands and an island joined to a French territory of similar name, has a unique political context that explains Jacobs's common references to Dutch and French and European aid in response. Taiwan has a similarly unique 
political context that could explain President Ing-wen's calls for 'international responsibility (and) full international cooperation.'

A rhetorical tool used across leaders was the emphasis on patriotic duty to encourage sacrifice. Twelve countries (seven men-Brazil, Dominican Republic, France, India, South Africa, UK, USA; five women-Bolivia, New Zealand, Norway, Scotland, Taiwan) used language calling on the public to love their country, serve their nation, or come together as one. In 11 countries, this went a step forward and called for self-sacrifice in the name of patriotism or service to the greater common good (five menDominican Republic, France, South Africa, UK, USA; six women-Belgium, Bolivia, New Zealand, Norway, Scotland, Taiwan). Notably, some of the women emphasised that this sacrifice is made for others-such as Wilmès's statement on 5 April: 'The sacrifices we make are very great, especially for people who are alone' or Solberg on 12 March: 'We must put life and health first anyway. For each other. And for all those we love.' Johnson, Macron, Medina and Ramaphosa focused on acknowledging sacrifices or expressing gratitude for the sacrifices made by all citizens and specific subgroups, such as healthcare providers.

\section{Responsibility versus paternalism}

Leaders included in this analysis often conveyed the importance of citizens taking actions to protect themselves and adhere to governmental guidelines. This analysis highlights two forms of emotional appeal used to convey this message: responsibility and paternalism. We defined responsibility as rhetoric that encouraged individuals to act independently to adhere to guidelines and paternalism as rhetoric that employed tactics such as shame, guilt, or punishment to influence the desired behaviour. Both men and women leaders used these tactics equally, without a significant difference by gender. We found responsibility used by 15 of the leaders (8 men-Dominican Republic, France, India, Indonesia, Russia, South Africa, UK, USA; 7 women-Belgium, Bolivia, Germany, New Zealand, Norway, Scotland, Sint Maarten) and paternalism used by 12 (6 men-Dominican Republic, France, India, Indonesia, South Africa, USA; 6 women-Belgium, Bolivia, Germany, New Zealand, Scotland, Sint Maarten)

Leaders often balanced the use of paternalism and responsibility within a speech. One example of this was seen in Ardern's speech on 23 March. Initially she used more paternalistic language to emphasise the importance of adhering to guidelines:

That's why sticking to the rules matters. If we don't-if you hang out with that friend at a park or see that family member for lunch, you risk spreading COVID-19 and extending everyone's time in Level 4 ... Failure to play your part in the coming days will put the lives of others at risk. There will be no tolerance for that and we will not hesitate in using enforcement powers if needed.
This quote uses guilt of spreading COVID-19 and extending government restrictions as a means of motivating compliance. She later concludes her speech with responsibility, particularly focusing on empowering citizens to recognise the important role they play:

You may not be at work, but that doesn't mean you don't have a job. Your job is to save lives, and you can do that by staying home, and breaking the chain...And finally, if you have any questions about what you can or can't do, apply a simple principle. Act like you have COVID-19. Every move you then make is a risk to someone else. That is how we must all collectively think. That's why the joy of physically visiting other family, children, grandchildren, friends, neighbours is on hold. Because we're all now putting each other first. And that is what we as a nation do so well. So New Zealand, be calm, be kind, stay at home. We can break the chain.

Other examples of responsibility include addressing the importance of personal responsibility and taking ownership of the pandemic. This was displayed by South Africa's President Cyril Ramaphosa on 3 March, 'Let us not make the mistake of thinking this is somebody else's problem;' Belgium's Prime Minister Sophie Wilmès on 19 March, 'Each of us has a role to play. Not only to protect ourselves, but also to protect our loved ones and our fellow citizens'; and UK's Prime Minister Boris Johnson on 20 March, 'Each and every one of us is now obliged to join together. To halt the spread of this disease. To protect our NHS and to save many, many thousands of lives.' Here responsibility highlights social contracts and the duty to protect other citizens. Paternalism was often partnered with language around the enforcement of policies by other citizens or the government, as used by Ardern. Examples include Indonesian President Joko Widodo on 20 March, 'Don't hesitate to reprimand those who are not disciplined in keeping the distance, washing their hands, and maintaining their health' and Sturgeon on 22 March 'My message to them is close now. We will have emergency powers within days to force you to close and we will use these powers if we have to. But you should not wait for that.' Collectively, paternalism and responsibility were important tools of emotional rhetoric used by all leaders to motivate their citizens to adhere to newly implemented guidelines.

\section{Emotional appeals}

A common rhetorical tool throughout the pandemic, and even across infectious disease discourse, is the use of war analogies - likening an outbreak to a war. Ten of the included leaders specifically describe the pandemic as a 'war' or 'battle (five women-Bangladesh, Bolivia, Norway, Scotland, Taiwan; five men-Dominican Republic, France, India, UK, USA). This number expands to 17 when we consider the use of any war rhetoric such as words along the lines of 'fighting' and 'enemy'. As seen in table 4, while this metaphor is used across genders, the frequency and aggression of these analogies seems to be stronger with the men. In the 19 speeches made 
Table 4 Leaders' use of war metaphors across speeches

\begin{tabular}{lccc}
\hline Country & No of references & $\begin{array}{l}\text { No of speeches (of total } \\
\text { speeches) }\end{array}$ & $\begin{array}{l}\text { Average reference coverage } \\
\text { per speech, \% }\end{array}$ \\
\hline Bangladesh* & 3 & 1 (of 1) & 3.04 \\
\hline Belgium* & 9 & 3 (of 3) & 3.19 \\
\hline Bolivia* $^{*}$ & 26 & 5 (of 7) & 10.00 \\
\hline Dominican Republic & 1 & 1 (of 2) & 0.61 \\
\hline Finland* & 1 & 1 (of 3) & 1.37 \\
\hline France & 9 & 1 (of 2) & 3.65 \\
\hline India & 30 & 4 (of 4) & 5.39 \\
\hline Indonesia & 2 & 1 (of 4) & 1.96 \\
\hline New Zealand* & 4 & 2 (of 3) & 2.21 \\
\hline Niger & 7 & 2 (of 2) & 3.95 \\
\hline Norway* & 4 & 2 (of 12) & 1.60 \\
\hline Scotland* & 4 & 2 (of 14) & 1.29 \\
\hline Sint Maarten & 1 & 1 (of 12) & 0.59 \\
South Africa & 1 & 1 (of 3) & 1.49 \\
\hline Taiwan* & 2 & 2 (of 2) & 1.87 \\
\hline UK & 3 & 7 (of 12) & 4.76 \\
\hline USA & 15 & 23 (of 25) & 4.51 \\
\hline
\end{tabular}

${ }^{*}$ countries with women heads of government.

by women who used war metaphors, they average 6.1 references to this rhetoric. In the 40 speeches made by men with this language, they average 25.4 references to war metaphors. For example, Trump used war analogies 136 times across 23 speeches, Johnson 15 times across 7 speeches, Modi 30 times across all 4 of his speeches. Meanwhile, the only woman to use this rhetoric in double digits was Áñez with 26 occurrences in her 5 speeches. On average, for speeches that did employ war rhetoric or aggressive language, it constituted $3.5 \%$ of each speech made by men, and $2.8 \%$ for the women (1.9\% without Áñez).

The language around war ranged in describing the battles, enemies, and weapons employed in the fight against COVID-19. On 16 March, Macron states: 'We are at war, admittedly a health war: we're fighting neither an army nor another nation. But the enemy is there, invisible, elusive, and it's making headway.' Four other leaders also describe the virus as an 'invisible enemy' (Issoufou, Johnson, Solberg and Trump) and Johnson even declares it 'the invisible killer' on 23 March, just days before announcing his own illness. Issoufou and Ardern equate options for response to the pandemic to weapons. For example, on 17 March Issoufou explains 'The only weapon that exists today is prevention.'

Bolivia's Áñez was the woman leader with the most war references, for example expressing on 15 March: 'I will dedicate $100 \%$ of my time to fighting for the health of Bolivians. It will be a tough battle and it will be a long one but I want you to know that it is a battle that we are going to win if we do it among all Bolivians. 'In observing Áñez's use of this language, it is relevant to consider the context of her political power as well. In addition to being the only woman in this dataset to reference war in the double digits, she is also the only leader in this pool who came to power after a coup. It is worth noting how the political and societal context of the country, Bolivia, could influence the language used by their head of government. Notably, both times Ing-wen employs the war metaphor, it is to describe the necessity for 'full international cooperation (as) the only way to ensure that the international community can win this battle.' In the case of Ing-wen, it is worth noting that Taiwan is the smallest state included in this analysis and it is possible that its contested relationship with China influences views on globalisation and international cooperation.

Another similarity among a group of the men leaders was to describe the pandemic or response measures in a blasé manner. In Brazil, India, the UK and the USA, heads of government often dismissed the severity and concern over COVID-19. On 24 March, Bolsonaro explained, 'In my particular case, due to my athlete's history, if I was infected by the virus, I would not have to worry, I would not feel anything or I would be, at most, suffering from a light influenza or a light cold, as the wellknown doctor from that well-known television said." This personal nonchalance was clear in another speech a week later when he said "The coronavirus came and 1 hour it will go away, unfortunately we will have losses along the way." Similarly, Modi and Johnson stress that 'everything is okay' and the need for 'going about our business as usual,' respectively. This same attitude is demonstrated in 
the way Trump discusses the voluntary nature of wearing face masks on 3 April: 'So with the masks, it's going to be, really, a voluntary thing. You can do it. You don't have to do it. I'm choosing not to do it, but some people may want to do it, and that's okay. It may be good. Probably will. They're making a recommendation. It's only a recommendation. It's voluntary.'

This approach is a stark contrast to the language employed by some of the women leaders in this analysis. It was more common for women to stress empathy and compassion in their speeches to the public. One poignant example is Norway's press briefings held specifically for children. On multiple occasions, Solberg held these events to answer the questions and concerns of the nation's children, including on 16 March when she said: 'Many children find this scary. I understand that well. It's allowed to get a little scared when so many big things happen at once. It is allowed to be a little scared to get infected by the coronavirus.' Women leaders such as Áñez and Ardern also empathised with parents and families by stressing their experiences as mothers. While the men leaders included in this analysis also have children, none of them mentioned their roles as fathers or experiences with family. In the case of Scotland's Sturgeon, this empathy included messages to the families who have lost loved ones to COVID-19 during the pandemic. Sturgeon began every speech with acknowledging the new deaths or hospitalisations in the country and explicitly sharing her condolences with those families and the public as a whole. She does this with honesty and compassion, for example on 5 April with, 'The figure I will report tomorrow, is likely to be artificially low-though of course, each one matters and is a source of sadness to family and friends but also to me.'

Women leaders including Áñez, Ardern, Jacobs, Merkel and Sturgeon called on their constituents to employ this empathy in their adherence to various restrictions and policies that may have been implemented. On $19 \mathrm{March}$, Merkel stressed: 'These are not just abstract numbers in statistics, but this is about a father or grandfather, a mother or grandmother, a partner - this is about people. And we are a community in which each life and each person counts." Áñez used similar language on $25 \mathrm{March}$, asking the audience to think of their parents and grandparents who took care of them in the past and needed to be protected now. Ardern and Sturgeon emphasise a need to 'be kind' and Jacobs implores society to 'show love and caring to one another.'

The strongest emotional appeal from the men leaders came from the Dominican Republic's now Former President Danilo Medina. Both of his speeches in March included vivid calls for solidarity and compassion, and on 17 March he concluded his speech with:

It is true, we are facing the most serious public health alert in recent decades, but we are also facing one of the moments in history that shows us the true greatness of human beings. Being a Dominican has always meant facing challenges with courage and facing the future with optimism and this time will be no exception. Let's not let fear cloud our gaze. Let us divest ourselves of all selfishness and see in each compatriot a member of our great family. Let us act with temperance, with rationality and always thinking about what is really important, what should unite us now, what we all want to preserve: the health of our grandparents and parents, of all those who are now more vulnerable and, of course, of our sons and daughters.

\section{DISCUSSION}

The purpose of this study is to analyse how a leaders' gender may relate to their communication style during the initial response to the COVID-19 pandemic, rather than to declare whether countries led by men or women managed the early months of the pandemic more effectively. In this study, we specifically focus on the content of communications by heads of government, their communication style, and the differences in these approaches. Previous research that has correlated specific public health metrics with leaders' gender suggests countries led by women may demonstrate slightly more success. ${ }^{34}$ However, others have emphasised that factors such as governance and existing capacity are also at play. ${ }^{6}$ The differences in both pandemic response and in communication are influenced by more than just gender, including a complex interplay of geographic context, political ideologies, socio-economic context, political history of the country, current social movements, and population demographics. Societal norms and expectations from the public audience may also influence how a leader chooses to address their citizens, which must be considered in assessing the efficacy of their communication. Furthermore, the course and timeline of COVID-19 has varied across countries which would influence how leaders communicate about the pandemic, yet this study focuses on a specific window in the early months of the pandemic. Our analysis shows that there are notable differences between men and women heads of government with practical implications for pandemic response.

Message-framing and communication from political actors is influenced by context and the audience they are aiming to reach. As a result, the public of a nation may influence their leader's communication approach in the same way that the leader's messaging affects them. Previous studies have described how the message-framing of leaders can influence decision-making processes and behaviour on micro and macro scales-from vaccination behaviour to trust in outbreak preparedness. ${ }^{2}$ 7-9 According to the agenda-setting research paradigm, ${ }^{10}$ messages highlighted in media or by leaders influence the selection and prioritisation of issues in society as well as policy-agenda-setting. In fact, messages shared by opinion leaders through media are more likely to impact policy both by shaping public perception of risk and by shaping policy makers' perception of public opinion. Government communication style is therefore likely to be associated with perceptions, responses to health threats, 
resulting in health, social, and economic outcomes for the public and nation. ${ }^{11}$ For example, President Obama's use of the term 'epidemic' rather than 'outbreak' during the 2014-2016 West Africa Ebola epidemic transformed the language being used by the media to describe the growing emergency. ${ }^{12}$ This transition of terminology went beyond semantics, affecting the conceptualisation of the crisis and therefore the resulting response. Communication and trusted information sharing in the COVID-19 pandemic has continued to play an important role in response. ${ }^{13}$ In the era of "fake news," it is often challenging for the public to discern misinformation from the truth which is why one study's findings that links $38 \%$ of COVID-19 misinformation conversations to President Trump raises concerns. ${ }^{14}$

This analysis highlights noticeable differences between the content men and women leaders used related to economics and social welfare and how they made emotional appeals to the public. While all leaders acknowledged the economic impacts of the pandemic, women were more likely to cite the impact on the microscale, emphasising the impact on individuals and families. This continued in the way men and women leaders described social welfare mechanisms versus financial relief. In particular, only women acknowledged the impact of the pandemic on unique vulnerable groups including migrants and refugees, substance abusers, people with mental health challenges, and its impact on family care responsibilities and domestic violence. While we did not assess governments' actual programmatic responses or policies, the focus on vulnerable populations by women heads of government demonstrates the prioritisation of vulnerable populations and social cohesion in their speeches.

Another clear difference across genders was the varying approaches in making emotional appeals. Across the board, men tended to use more war rhetoric while women tended to employ personal or empathetic appeals. Language that uses imagery of battles and threatening enemies can be a powerful tool to invoke fear in the audience. ${ }^{1516}$ As an example, Prime Minister Johnson explicitly stated that 'we must act like any wartime government and do whatever it takes to support our economy.' Times of war require unprecedented action from the government in order to protect the populace. However, the fear and sense of urgency invoked by this language can also be used as a justification for a lack of transparency. ${ }^{17}$ Labelling the COVID-19 pandemic as a war can influence response mechanisms, proposed policies, and media coverage in a cyclical fashion. ${ }^{18}$ In times of crisis, those in charge may be quick to fall back on existing structures of response that are not transparent. ${ }^{17}$ The decisions made in these times, particularly in attempting to mitigate a disease outbreak, will invariably affect and rely on the public. Yet, when decisions are taken behind closed doors, how they are communicated to the public impacts on public trust and compliance with public health measures. It is precisely and especially during emergencies that the public requires transparent procedures and clearly communicated decisions. Building trust and enabling accountability depend on it, underpinning not only an efficient outbreak response but also an effective health system. ${ }^{19}$ Accountability and transparency are critical to earn the public's trust and shared information must be evidence-based. Elected officials must have some level of understanding of health and risk communication in order to communicate effectively in times of health crises, as well as the skills to translate science into policy to ensure evidence-based priorities and policy implementation. ${ }^{20}$

The empathetic and personal appeals that women made focused on compassion and social cohesion, such as Chancellor Merkel's comment, 'these are not just abstract numbers in statistics, but this is about a father or grandfather, a mother or grandmother, a partner-this is about people. And we are a community in which each life and each person counts.' Similar comments asking for compassion for others were seen consistently throughout speeches made by women. Commentators have picked up on these emotional appeals as being vital for generating social cohesion to generate a unified public response. ${ }^{21}$ In particular, Prime Minister Ardern has been hailed for her ability to generate trust through transparency and action through the social cohesion she inspires. ${ }^{22}$ Empathic statements and war rhetoric may both inspire a form of unity, but they have important practical differences. While war rhetoric plays to a collectivism based on fear and division, empathy appeals to a collectivism based on compassionate social cohesion. ${ }^{23} \mathrm{~A}$ fear-based approach may instigate conflict and marginalisation. ${ }^{24} 25$

There are several limitations to this study. As with qualitative research, there is a limit to the comparability and generalisability of the data analysed. Any analysis relating to the gender of leaders is also limited in making statistically significant conclusions due to the small population of women situated as heads of government. This study relied on publicly available data that could be transcribed or translated to English with limited resources, which also made some speeches subject to errors in transcription and translation. Due to this and other differences among countries, the number of speeches from each country varies greatly. However, it is worth noting that there the same amount of speeches from men $(n=61)$ and women $(\mathrm{n}=61)$ included. Additionally, this study does not attempt to measure how speeches made by heads of government were received by the public or to what degree they build public trust. While we discuss the importance of clear and transparent communication as one factor of establishing trust, there is not a specific metric that can demonstrate this.

In identifying gender, we did not directly ask heads of government for their gender identity, but instead relied on gender identities reported in the news and through pronouns in speeches. We acknowledge, however, that gender is complex, self-identified, non-binary, and socially produced. Additionally, this analysis did not take 
into account the teams of speechwriters or other individuals (or their gender identities) who may influence the language in speeches delivered by heads of government. Countries have also been impacted differently by the pandemic (incidence, prevalence, mortality rate) and have had different experiences with managing public health emergencies, which can affect their response, priorities, political and risk communication styles. This study did not consider this historical context nor the societal and political ideals and values of national constituents that influence individual leaders, the language they use, and political priorities. Finally, it is important to acknowledge that these contexts and the public citizens of leaders' public speeches may bias what the head of government chooses to say or how to address their audience. This influence of the audience on the speaker was not considered in this analysis, but raises meaningful questions for future investigation.

\section{CONCLUSION}

While this analysis does not attempt to answer whether men or women are more effective leaders in responding to the COVID-19 pandemic, it does provide insight into the rhetorical tools and types of language used by different leaders during a national and international health crisis. This language matters because it influences how leaders inspire citizens' compliance with response and recovery measures. This analysis explores how men and women heads of government tend to use different types of language. There are certainly exceptions, but this study contributes to the narrative on how communication is in shaping a public health response through dialogue and building public trust.

We have seen in previous disease outbreaks, and during the COVID-19 pandemic, how a fear-based or nonchalant narrative can be disastrous for an effective response. ${ }^{26-29}$ This highlights the critical role that communication plays in public health. ${ }^{30}$ There is more to learn about how the discourse around COVID-19 influences the pandemic response, however the impacts of this pandemic are far-reaching and far from over. We specifically illustrate important differences around gender, which should be further explored in future studies and related to effective response. As our world becomes more globalised and public health matters affect all of us, this era will reshape how public facing officials discuss both response and recovery policies. While it has been overlooked in the past, this study contextualises the importance of language, through a gender lens, in communicating with the public and its potential influence on a public health response. As a result, there is a need for more robust studies on communications in public health as we consider how the way we communicate will affect vaccine deployment as well as economic and social recovery.

\section{Author affiliations}

${ }^{1}$ Vayu Global Health Foundation, Boston, Massachusetts, USA
${ }^{2} U C D$ Centre for Interdisciplinary Research, Education and Innovation in Health Systems, School of Nursing, Midwifery and Health Systems, University College Dublin, Dublin, Ireland

${ }^{3}$ Women in Global Health, Washington, District of Columbia, USA

${ }^{4}$ Harvard Medical School, Boston, Massachusetts, USA

${ }^{5}$ Department of Community and Family Health, University of South Florida, Tampa, Florida, USA

${ }^{6}$ Division of General Internal Medicine, Department of Medicine, Georgetown University School of Medicine, Washington, District of Columbia, USA

${ }^{7}$ Institute for Advanced Study of the Americas, University of Miami, Miami, Florida, USA

Twitter Sara Dada @dadasara3, Henry Charles Ashworth @HenryCAshworth, Marlene Joannie Bewa @BEWAJ and Roopa Dhatt @RoopaDhatt

Acknowledgements The authors would like to acknowledge Salla Atkins (Tampere University, Finland), Veronica Velasquez (Northwestern Trauma and Surgical Initiative, USA), Kaushi Ratnayake (Harper and Keele Veterinary School, UK), Alina Sobitschka (University of Göttingen, Germany), Andreia Bruno-Tomé (Monash University, Australia), Mehr Manzoor (Tulane University, USA), Daniela Suarez-Rebling (Icahn School of Medicine at Mount Sinai, USA) for transcription and/or translation assistance. We would also like to thank Rick Zednik (Women Political Leaders), Emma Kinloch (King's College London, UK), and Kim van Daalen (Cambridge University, UK) for their feedback on methodology and approach, Ann Keeling (Women in Global Health) for her review of the manuscript, and Lilly Khorsand (Women in Global Health) for assisting with table graphics.

Contributors SD developed the study methodology with the guidance of RD and collected the data for this study. SD and HCA conducted the analysis and wrote the initial draft, with key input from JB. RD provided edits and feedback. All authors revised the manuscript before submission.

Funding Funding for the publication fees of this research was provided by the Bill \& Melinda Gates Foundation (INV-005944).

\section{Competing interests None declared.}

Patient consent for publication Not required.

Ethics approval This research did not require an institutional board review approval. Data were collected online from publicly available and accessible speeches and did not involve any human subjects.

Provenance and peer review Not commissioned; externally peer reviewed.

Data availability statement All data are available in the public domain at the links provided in the supplementary material. Specific transcript data can also be shared on request.

Supplemental material This content has been supplied by the author(s). It has not been vetted by BMJ Publishing Group Limited (BMJ) and may not have been peer-reviewed. Any opinions or recommendations discussed are solely those of the author(s) and are not endorsed by BMJ. BMJ disclaims all liability and responsibility arising from any reliance placed on the content. Where the content includes any translated material, BMJ does not warrant the accuracy and reliability of the translations (including but not limited to local regulations, clinical guidelines, terminology, drug names and drug dosages), and is not responsible for any error and/or omissions arising from translation and adaptation or otherwise.

Open access This is an open access article distributed in accordance with the Creative Commons Attribution 4.0 Unported (CC BY 4.0) license, which permits others to copy, redistribute, remix, transform and build upon this work for any purpose, provided the original work is properly cited, a link to the licence is given, and indication of whether changes were made. See: https://creativecommons.org/ licenses/by/4.0/.

\section{ORCID iDs}

Sara Dada http://orcid.org/0000-0003-3910-1856

Henry Charles Ashworth http://orcid.org/0000-0002-8989-8560

Marlene Joannie Bewa http://orcid.org/0000-0002-2092-293X

Roopa Dhatt http://orcid.org/0000-0002-0744-7708

\section{REFERENCES}

1 Antonakis J, d'Adda G, Weber R. Just words? just speeches? on the economic value of charismatic leadership. NBER Rep 2014;4. 
2 Ajzenman N, Cavalcanti T, Da Mata D. More than words: Leaders' speech and risky behavior during a pandemic, 2020.

3 Purkayastha S, Salvatore M, Mukherjee B. Are women leaders significantly better at controlling the contagion during the COVID-19 pandemic? J Health Soc Sci 2020;5:231-40.

4 Garikipati S, Kambhampati U. Leading the Fight Against the Pandemic: Does Gender 'Really’Matter? 2020.

5 McHugh ML. Interrater reliability: the kappa statistic. Biochem Med 2012;22:276-82.

6 Piscopo JM. Women Leaders and Pandemic Performance: A Spurious Correlation. Politics \& Gender, 2020: 1-9.

7 Yano M. Covid-19 pandemic and politics: the cases of Florida and Ohio. research Institute of economy, trade and industry. RIETI, 2020.

8 Broom J, Broom A, Bowden V. Ebola outbreak preparedness planning: a qualitative study of clinicians' experiences. Public Health 2017;143:103-8.

9 Hendrix KS, Finnell SME, Zimet GD, et al. Vaccine message framing and parents' intent to immunize their infants for MMR. Pediatrics 2014;134:e675-83.

10 McCombs ME, Shaw DL. The Agenda-Setting function of mass media. Public Opin Q 1972;36:176-87.

11 DKD K, Kreps GL. An analysis of government communication in the United States during the COVID-19 pandemic: recommendations for effective government health risk communication. World Medical \& Health Policy, 2020.

12 Gesser-Edelsburg A, Shir-Raz Y, Bar-Lev OS, et al. Outbreak or epidemic? how Obama's language choice transformed the Ebola outbreak into an epidemic. Disaster Med Public Health Prep 2016;10:669-73.

13 Newton K, Communications G. Government communications, political trust and compliant social behaviour: the politics of Covid-19 in Britain. Polit Q 2020;91:502-13.

14 Evanega S, Lynas M, Adams J. Coronavirus misinformation: quantifying sources and themes in the COVID-19 'infodemic', 2020.

15 Shors L. Council on foreign relations, 2020. Available: https://www. thinkglobalhealth.org/article/waging-another-public-health-war

16 Flusberg SJ, Matlock T, Thibodeau PH. War metaphors in public discourse. Metaphor Symb 2018;33:1-18.

17 vanDaalen K, Bajnoczk C, Chowdhury M. Symptoms of a broken system: the gender gaps in COVID-19 decision-making. BMJ Global Health;2020.

18 Larson BM, Nerlich B, Wallis P. Metaphors and biorisks: the war on infectious diseases and invasive species. Sci Commun 2005;26:243-68.

19 UHC 2030 International Health Partnership. Living with COVID-19: time to get our act together on health emergencies and UHC, 2020.

20 Burkle FM, Hanfling D. Political leadership in the time of crises: primum non nocere. PLoS Curr 2015;7:fd8aaf6707cd5dd252e33c771d08b949. doi:10.1371/ currents.dis.fd8aaf6707cd5dd252e33c771d08b949

21 Anderson C. Why do women make such good leaders during COVID-19? Forbes 2020;19.

22 Friedman U. New Zealand's Prime Minister may be the most effective leader on the planet. 19. The Atlantic, 2020.

23 Fear RSV. Rhetoric, and the "Other", Race/Ethnicity: Multidisciplinary Global Contexts. , 2011: 4, 405-18.

24 Shen L. The effectiveness of empathy- versus fear-arousing antismoking PSAs. Health Commun 2011;26:404-15.

25 Ruiter RAC, Kessels LTE, Peters G-JY, et al. Sixty years of fear appeal research: current state of the evidence. Int J Psychol 2014;49:63-70.

26 Asmundson GJG, Taylor S. Coronaphobia: fear and the 2019-nCoV outbreak. J Anxiety Disord 2020;70:102196.

27 Atkinson P. Open Democracy [Internet], 2014. Available: https:// www.opendemocracy.net/en/ebola-crisis-exposing-failures-of-localand-global-governance/

28 Simpson JK. Appeal to fear in health care: appropriate or inappropriate? Chiropr Man Therap 2017;25:27.

29 Tumpey AJ, Daigle D, Nowak G. Communicating during an outbreak or public health investigation. $C D C$, epidemic intelligence service, 2018.

30 Qiu W, Chu C, Hou X, et al. A comparison of China's risk communication in response to SARS and H7N9 using principles drawn from international practice. Disaster Med Public Health Prep 2018;12:587-98.

31 World Health Organization. Coronavirus disease (COVID-19): situation report - 162, 2020.

32 The World Bank. GDP per capita (current US\$). Available: https:// data.worldbank.org/indicator/NY.GDP.PCAP.CD?most recent_year desc=true

33 Democracy Index 2019. The Economist intelligence unit, 2020.

34 United Nations Development Programme. Human development reports: gender development index (GDI)

35 Clark D. Gdp per capita in Scotland 2000-2019, 2020. Available: https://www.statista.com/statistics/348383/scotland-gdp-percapita/\#: :text=The\%20gross\%20domestic\%20product\%20per, pounds $\% 20$ when $\% 20$ compared $\% 20$ with $\% 202018$

36 United Nations. Per capita GDP at current prices - US dollars. Available: http://data.un.org/Data.aspx?q=sint+maarten\&d= SNAAMA\&f=grlD\%3A101\%3BcurrID\%3AUSD\%3BpcFlag\%3A1\% 3BcrID\%3A534

37 World Economic Outlook Database. International monetary fund, 2019. Available: https://web.archive.org/web/20200925143433/ https://www.imf.org/external/pubs/ft/weo/2019/02/weodata/ weorept.aspx?pr.x $=43 \&$ pr.y $=11 \&$ sy $=2016 \&$ ey $=2021 \&$ scsm $=1 \&$ ssd $=$ $1 \&$ sort $=$ country\&ds $=. \& b r=1 \& c=528 \& s=N G D P \quad R P C H \% 2 C N G D P D \%$ 2CPPPGDP\%2CNGDPDPC\%2CPPPPC\%2CPCPIPCH\&grp=0\&a= 